Original Research Paper

\title{
Efficacy of fumigation Medang wood (Chinnamomum javanicum) at different times against Schizophyllum commune Fries fungus
}

\author{
Farah Diba $^{1 *}$, Lolyta Sisillia ${ }^{1}$, Juan Arif Tertiadi ${ }^{1}$ \\ ${ }^{1}$ Fakultas Kehutanan Universitas Tanjungpura, Pontianak, Indonesia
}

\author{
Article History \\ Received : August 15 ${ }^{\text {th }}, 2021$ \\ Revised : August 29, 2021 \\ Accepted : September 06 ${ }^{\text {th }}, 2021$ \\ Published : September $16^{\text {th }}, 2021$ \\ *Corresponding Author: \\ Farah Diba, \\ Fakultas Kehutanan Universitas \\ Tanjungpura, Pontianak, \\ Indonesia; \\ Email: \\ farahdiba@fahutan.untan.ac.id
}

\begin{abstract}
The use of wood for the timber industry increases, but wood with a high natural durability class, especially class I \& II was limited. Efforts to improve the quality of wood are needed. The research purposed to increase the durability of Medang wood (Chinnamomum javanicum) with the preservation methods using fumigation and evaluated against Schizophyllum commune Fries fungi. Medang wood from gubal area was achieved from Kubu Raya Regency and made into a sample for preservation treatment measuring $5 \mathrm{~cm} \times 2 \mathrm{~cm} \times 2 \mathrm{~cm}$. The wood preservation methods used fumigation. The fumigation process used an oven and time of fumigation consisting of 12 hours, 24 hours, and 36 hours. The temperature process was $80^{\circ} \mathrm{C}$. After preservation, the wood was tested against Schizophyllum commune Fries based on SNI 72072014. The result of preservation showed that the fumigation process changed the color of Medang wood. The color changed from white pale into brown (12 hours fumigation), dark brown ( 24 hours fumigation), and very dark brown (36 hours fumigation). The weight loss of Medang wood after 12 weeks attacked by Schizophyllum commune Fries fungi was range between $2.45 \%-3.44 \%$. The weight loss of Medang wood on treatment 12 hours fumigation was $3.44 \%$, on treatment 24 hours was $3.34 \%$ and on the treatment of 36 hours was $2.45 \%$. After the fumigation methods, the durability of Medang wood increased into II class. The compound from smoke during the fumigation process, which functions as antifungi, was phenol. The optimum treatment to increase the durability of Medang wood was fumigation for 36 hours with a temperature of $80^{\circ} \mathrm{C}$.
\end{abstract}

Keywords: Chinnamomum javanicum; fumigation; Schizophyllum commune; wood preservation

\section{Pendahuluan}

Kebutuhan penggunaan kayu, baik untuk industri perkayuan dan kontruksi semakin meningkat dengan bertambahnya jumlah penduduk. Berdasarkan penelitian Jasni (2016) sebagian besar jenis kayu di Indonesia memiliki tingkat keawetan yang rendah. Penggunaan kayu kelas awet rendah memerlukan perlakuan untuk meningkatkan keawetan dan umur pakai kayu. Mariana et al. (2013) menyatakan kayu yang memiliki kelas awet rendah sangat rentan terhadap serangan organisme perusak kayu sepeti rayap dan jamur, dan harus diberikan perlakuan pengawetan untuk meningkatkan masa pakai kayu. Juanita et al. (2020) menyatakan jamur This article is licensed under a Creative Commons Attribution 4.0 International License. perusak kayu yang menimbulkan kerugian ekonomi tinggi adalah jamur Schizophyllum commune Fries. Kerusakan yang ditimbulkan oleh jamur $S$. commune meliputi pada pohon yang masih hidup (Susan dan Retnowati 2017), kayu log yang baru ditebang (Iramayana et al. 2019), produk turunan kayu seperti furniture (Debnath et al. 2017), rotan dan bambu (Fitria et al. 2012). Herliyana et al. (2011) menyatakan jamur $S$. commune adalah jenis jamur pelapuk kayu yang digunakan sebagai standar untuk pengujian keawetan alami kayu.

Kayu Medang (Chinnamommum javanicum) merupakan kayu kelas awet III yang memiliki kerapatan $0,57 \mathrm{~g} / \mathrm{cm}^{3}$ (Istikowati et al. 2019) dan banyak digunakan sebagai kayu (C) 2021 The Author(s). This article is open access 
konstruksi, bahan baku pulp dan kertas serta kayu bahan kerajinan. Mulia et al. (2017) menyatakan kayu Medang termasuk dalam famili Lauraceae yang memiliki nilai ekonomi penting. Genus Chinnamomum termasuk pohon yang tumbuh dan tersebar di Sumatera, Jawa, Kalimantan dan Sulawesi. Hasil penelitiannya menyatakan di Cagar Alam Dungus Iwul, kayu Medang memiliki nilai kerapatan relatif sebesar 2,13\%. Istikowati et al.(2016) menyatakan kayu Medang memiliki kandungan holoselulosa sebesar $50,7 \%, \alpha$-selulosa sebesar $80,8 \%$, kandungan zat ekstraktif kayu sebesar 2,1\%, kandungan lignin sebesar 25,0\% dan bilangan runkel sebesar 0,45 $\pm 0,05$. Komposisi kimia kayu Medang yang banyak mengandung selulosa menyebabkan kayu Medang rentan terhadap serangan jamur. Selanjutnya penelitian Istikowati et al. (2014) menyatakan kayu Medang yang berasal dari hutan sekunder di Kalimantan Selatan memiliki berat jenis sebesar $0,55 \mathrm{~g} / \mathrm{cm}^{3}$ dan hal ini menyebabkan kayu dapat digunakan dengan baik sebagai bahan konstruksi. Kayu Medang di Kalimantan Barat banyak digunakan sebagai bahan konstruksi seperti tiang dan papan lantai dan untuk kayu kerajinan khususnya penggunaan kayu sebagai kerajinan miniatur tugu khatulistiwa. Hasil produk kerajinan kayu dari kayu Medang mudah terserang oleh jamur Schizophyllum commune, karenanya tindakan pengawetan untuk meningkatkan keawetan kayu Medang terhadap jamur sangat penting dilakukan.

Salah satu metode pengawetan kayu yang mudah diaplikasikan adalah dengan metode pengasapan kayu. Penus et al. (2016) meneliti pengaruh lama pengasapan pada kayu Laban dan Akasia, proses pengasapan dilakukan dengan oven dan waktu pengasapan terdiri atas tiga perlakuan yaitu 12 jam, 24 jam dan 36 jam, dalam meningkatkan sifat fisik dan mekanik kayu. Hasil penelitian menyatakan waktu pengasapan 12 jam meningkatkan sifat fisik kayu yang meliputi kadar air, berat jenis, dan perubahan dimensi dan sifat mekanik kayu berupa kekerasan kayu. Waktu pengasapan kayu Laban dan Akasia selama 24 jam menghasilkan peningkatan pada nilai keteguhan tekan sejajar arah serat kayu. Forlius et al. (2017) meneliti pengasapan kayu yang dilakukan secara tradisional oleh masyarakat yang meliputi lama pengasapan tiga jam pada pagi hari dan dilanjutkan tiga jam pada sore hari, dan proses pengasapan dilakukan selama dua belas hari pada ruangan tertutup (tanpa oven). Sampel uji yang digunakan adalah kayu Akasia dan kayu Laban. Hasil penelitian menyatakan perlakuan pengasapan meningkatkan sifat fisik dan mekanik kayu. Penelitian Sisillia et al. (2018) menguji keawetan kayu Akasia dan kayu Laban yang telah diasapkan secara tradisional terhadap jamur Schizophyllum commune Fries. Hasil penelitiannya menyatakan kayu Akasia yang diasapkan memiliki nilai kehilangan berat sebesar 9,55\%, kayu Laban yang diasapkan memiliki nilai kehilangan berat sebesar $8,03 \%$ dan perlakuan pengawetan dengan metode pengasapan terbukti dapat meningkatkan kelas awet kayu Akasia dan Laban dari kelas IV menjadi kelas III.

Penelitian Andika et al. (2019) melakukan pengawetan kayu Bintangur dan Medang dengan metode pengasapan selama 12 jam dan 24 jam. Proses pengasapan dilakukan menggunakan oven kemudian kayu diuji keawetannya terhadap serangan rayap tanah Coptotermes curvignathus Holmgren. Hasil penelitian menunjukkan kayu Medang yang diasapkan selama 12 jam menghasilkan nilai mortalitas rayap sebesar $78,4 \%$ sedangkan pada kayu Bintangur sebesar $100 \%$. Perlakuan pengasapan selama 24 jam menghasilkan nilai mortalitas rayap sebesar $100 \%$ baik pada kayu Medang dan kayu Bintangur. Perlakuan pengawetan kayu dengan metode pengasapan dapat meningkatkan kelas awet kayu Medang dan Bintangur terhadap serangan rayap, yang semula kelas III naik menjadi kelas I.

Perlakuan pengasapan pada kayu Medang dapat meningkatkan keawetan kayu terhadap rayap tanah, namun belum diteliti ketahanannya dari serangan jamur Schizophyllum commune Fries. Lama waktu pengasapan menjadi salah satu faktor penentu keberhasilan metode pengawetan kayu dengan pengasapan. Oleh karena itu dilakukan penelitian dengan tujuan meningkatkan keawetan kayu Medang dengan metode pengasapan pada variasi lama waktu pengasapan. Tujuan khusus penelitian adalah melakukan pengujian keawetan kayu Medang yang diasapkan pada waktu berbeda terhadap serangan jamur Schizophyllum commune Fries, dan menganalisis waktu pengasapan yang optimal dalam meningkatkan keawetan kayu 
Medang terhadap jamur Schizophyllum commune Fries.

\section{Bahan dan Metode}

\section{Bahan dan Alat}

Bahan penelitian adalah kayu Medang (Chinnamomum javanicum) yang diperoleh dari hutan Desa Lingga Kecamatan Sungai Ambawang Kabupaten Kubu Raya. Kayu yang digunakan sebagai sampel uji adalah bagian kayu gubal. Ukuran sampel uji keawetan kayu Medang terhadap jamur mengacu kepada standar SNI 7207-2014 dengan ukuran $5 \mathrm{~cm}$ x $2 \mathrm{~cm}$ x $2 \mathrm{~cm}$.

Alat penelitian meliputi oven untuk pengasapan kayu Medang, autoclave untuk pembuatan media jamur dan sterilisasi alat, laminar air flow untuk proses isolasi jamur. Kegiatan pengujian kayu Medang terhadap jamur dilaksanakan di Laboratorium Teknologi Kayu Fakultas Kehutanan Universitas Tanjungpura.

\section{Prosedur Pengawetan Kayu}

Proses pengawetan kayu menggunakan metode pengasapan dengan oven yang didesain khusus dengan ukuran tinggi $50 \mathrm{~cm}$, panjang 50 $\mathrm{cm}$ dan lebar $50 \mathrm{~cm}$. Oven terdiri atas dua ruangan, ruangan pertama terletak di bagian bawah sebagai tempat pembakaran dan menghasilkan asap, dan ruangan bagian atas sebagai tempat pengasapan sampel kayu. Bahan yang digunakan untuk menghasilkan asap dalam proses pengawetan kayu Medang adalah tempurung kelapa yang diletakkan di bagian bawah oven sebanyak $10 \mathrm{~kg}$. Isolat jamur pelapuk kayu Schizophyllum commune Fries diperoleh dari isolat jamur yang terdapat di Laboratorium Teknologi Kayu Fakultas Kehutanan Universitas Tanjungpura.

Sampel kayu uji diikat dan digantung pada ruang oven bagian atas. Proses pengasapan dilakukan selama 12 jam, 24 jam dan 36 jam dan suhu pembakaran sebesar $80^{\circ} \mathrm{C}$. Jumlah masingmasing sampel uji untuk setiap perlakuan pengasapan adalah 5 sampel kayu. Setelah waktu pengasapan selesai, sampel kayu uji dikondisikan di dalam oven selama 60 menit, kemudian dimasukkan ke desikator selama 10 menit. Selanjutnya sampel uji ditimbang untuk mengetahui berat sampel kayu uji mula-mula sebelum diuji keawetannya terhadap jamur Schizophyllum commune Fries.

\section{Pengujian Keawetan Kayu Terhadap Jamur}

Kayu yang sudah diawetkan dengan metode pengasapan dianalisis perubahan warna menggunakan Munsell Colour Chart. Setelah analisis perubahan warna dilakukan pengujian keawetan terhadap jamur. Pengujian keawetan sampel uji kayu Medang terhadap jamur Schizophyllum commune Fries dilakukan berdasarkan standar SNI 7207-2014. Media potatoes dextrose agar (PDA) sebanyak $100 \mathrm{ml}$ dimasukkan pada wadah pengujian, yang sebelumnya sudah disterilkan di autoclave. Setelah media PDA mengeras, diletakkan isolat jamur Schizophyllum commune Fries berukuran $5 \mathrm{~mm}$. Selanjutnya diletakkan satu sampel uji kayu di atas isolat jamur, kemudian wadah ditutup dengan aluminium foil dan plastic wrap dan disimpan dalam inkubator selama dua belas minggu pada suhu ruang.

Jumlah semua sampel pengujian adalah 15 sampel uji kayu Medang yang diasapkan dengan waktu berbeda dan 5 sampel kayu Medang kontrol. Setelah dua belas minggu, sampel kayu uji dikeluarkan dari wadah uji, dibersihkan dan dimasukkan ke oven pada suhu $60^{\circ} \mathrm{C}$ selama tiga hari. Selanjutnya kayu ditimbang dan dihitung nilai kehilangan berat sampel uji kayu dengan menggunakan rumus Sisillia et al. (2017) sebagai berikut:

$$
\mathrm{WL}=\frac{W 1-W 2}{W 1} \times 100 \%
$$

\section{Keterangan:}

WL : Persentase kehilangan berat sampel uji (\%) $\mathrm{W} 1$ : Berat kering oven sampel uji mula-mula (g) W2 : Berat kering oven sampel uji setelah diserang jamur $(\mathrm{g})$

Analisis kelas awet kayu Medang yang diasapkan dan kayu kontrol setelah diserang jamur Schizophyllum commune Fries dilakukan berdasarkan standar SNI 7207-2014. Nilai persentase kehilangan berat sampel uji kayu Medang yang telah diperoleh dari hasil perhitungan setelah dua belas minggu diinkubasi bersama jamur Schizophyllum commune Fries diklasifikasikan pada kelas ketahanan kayu dan kelas awet kayu sesuai yang disajikan pada Tabel 1. 
Tabel 1. Kelas keawetan kayu berdasarkan ketahanan dari serangan jamur

\begin{tabular}{clc}
\hline $\begin{array}{c}\text { Kelas } \\
\text { Awet }\end{array}$ & Ketahanan Kayu & $\begin{array}{c}\text { Penurunan Berat } \\
\text { Kayu }(\%)\end{array}$ \\
\hline I & Sangat Tahan & $\leq 1$ \\
II & Tahan & $1-5$ \\
III & Agak Tahan & $5-10$ \\
IV & Tidak Tahan & $10-30$ \\
V & Sangat Tidak & $>30$ \\
& Tahan & \\
\hline
\end{tabular}

Sumber : SNI 7207-2014: Uji ketahanan kayu dan produk kayu terhadap organisme perusak kayu

\section{Hasil dan Pembahasan}

\section{Perubahan Warna Kayu}

Kayu Medang yang diasapkan mengalami perubahan warna kayu yang sangat berbeda dengan kayu Medang yang tidak diasapkan. Hasil analisis perubahan warna dengan Munsell Colour Chart menunjukkan warna kayu Medang yang tidak diasapkan adalah putih (white pale), setelah diasapkan selama 12 jam berubah menjadi coklat (brown), setelah diasapkan selama 24 jam berubah menjadi coklat tua (dark brown) dan setelah diasapkan selama 36 jam berubah menjadi coklat kehitaman (very dark brown). Perubahan warna kayu Medang sebelum dan setelah diasapkan disajikan pada Gambar 1 .

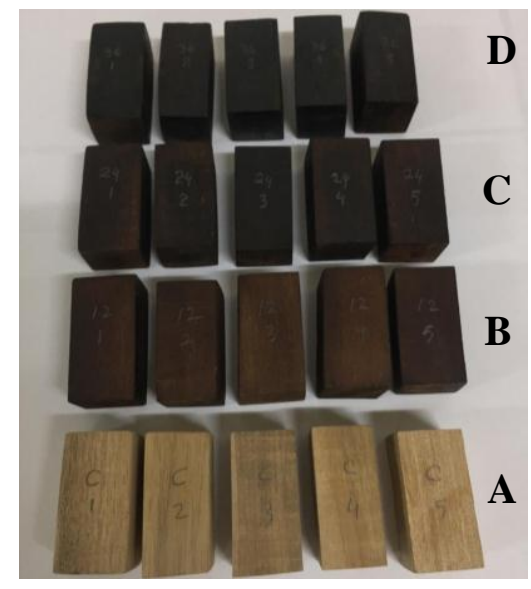

Gambar 1. Perubahan warna kayu Medang (Chinnamomum javanicum), A: sebelum diasapkan; B: diasapkan 12 jam; C: diasapkan 24 jam; D: diasapkan 36 jam
Kayu Medang yang diasapkan berubah warna menjadi gelap dan semakin lama proses pengasapan menghasilkan warna kayu yang menjadi lebih gelap, cenderung ke warna hitam. Hasil penelitian sejalan dengan hasil penelitian Ishiguri et al. (2005) yang menyatakan warna kayu yang diasapkan selama 200 jam lebih gelap dan mengkilap daripada kayu yang diasapkan selama 100 jam; dan penelitian Hadi et al. (2020a) yang menghasilkan kayu mangium (Acacia mangium) and sengon (Falcataria moluccana) dengan warna yang lebih gelap pada waktu pengasapan yang lebih lama.

Kayu Medang yang diasapkan memiliki permukaan kayu yang lebih mengkilap, halus dan licin serta aroma kayu lebih kuat disebabkan oleh asap yang terserap dalam pori-pori kayu. Diba dan Sisillia (2019) menyatakan kayu yang diasap kan menyerap senyawa yang terdapat pada asap, yang meliputi senyawa asam, alkohol, karbonil, ester, furan, lakton dan fenol. Proses pengasapan dengan panas menjadikan pori-pori kayu menjadi lebih cepat menyerap senyawa yang terdapat pada asap.

Husband dan Cranford (2019) menyatakan proses pengasapan menghasilkan reaksi dan ikatan senyawa kimia dari asap dengan senyawa kimia yang terdapat pada kayu. Komponen utama kayu adalah karbon, hidrogen dan oksigen dan proses pengasapan menghasilkan gas karbondioksida, gas nitrogen, senyawa karbonil, asam organik dan senyawa hidrokarbon. Ikatan antara senyawa yang dihasilkan oleh asap dengan senyawa kimia yang terdapat pada kayu menghasilkan perubahan warna kayu, permuka an kayu serta aroma kayu. Hadi (2017) menyata kan lama pengasapan memberikan pengaruh nyata pada perubahan warna kayu, yang disebabkan oleh penyerapan senyawa kimia dari asap oleh kayu dan membuat warna menjadi lebih gelap. Senyawa kimia yang terdapat pada asap meliputi asam asetat, metil alkohol, fenol, aldehid, dan keton.

Proses pengasapan menghasilkan perubah an warna, tidak hanya pada kayu tapi juga pada produk pangan seperti ikan dan daging. Royani et al. (2015) menyatakan pengasapan telah diguna kan sebagai metode pengawetan dan peningkatan mutu ikan tongkol oleh masyarakat di Kabupaten Maluku Tenggara. Produk ikan asap dikenal dalam bahasa lokal sebagai ikan asar dengan warna ikan coklat keemasan dan 
menjadi produk unggulan yang memberikan pendapatan ekonomi bagi masyarakat.

Pengasapan adalah proses penetrasi senyawa yang mudah menguap yang terdapat pada asap dari hasil pembakaran bahan lignoselulosa (Palm et al. 2011), menghasilkan emisi dari hasil pembakaran berupa campuran senyawa organik, senyawa anorganik, karbon dan metal (Bruns et al. 2015), menghasilkan aroma yang spesifik akibat interaksi antar senyawa yang terdapat di dalam asap, konsentrasi dari setiap senyawa dan penetrasi senyawa pada pori-pori kayu (Chhabra et al. 2011), menghasilkan perubahan warna karena penyerapan senyawa kimia dari asap berupa aldehid, keton, fenol, asam organik, karbonil, nitrooksida, ester, alkohol dan eter (Crippa et al. 2013).

Penelitian Bian et al. (2015) menyatakan kondisi asap dalam proses pengasapan dipenga ruhi oleh bahan baku, panas dan pengaturan nyala api. Suhu yang baik digunakan dalam proses pengasapan adalah $80^{\circ} \mathrm{C}-90^{\circ} \mathrm{C}$. Hadi et al. (2020b) meneliti pengaruh lama pengasapan pada empat jenis kayu yaitu kayu sengon (Falcataria moluccana), kayu mangium (Acacia mangium), kayu pinus (Pinus merkusii) dan kayu jabon (Anthocephalus cadamba) terhadap perubahan warna kayu dan menguji keawetan kayu dari serangan rayap tanah Coptotermes curvignathus Holmgren. Lama pengasapan yang digunakan meliputi 1 minggu, 2 minggu dan 3 minggu. Hasil penelitian menyatakan semakin lama waktu pengasapan kayu menghasilkan warna kayu yang cenderung lebih gelap karena senyawa kimia yang terdapat pada asap yang masuk ke sel kayu semakin banyak. Senyawa kimia yang terdapat pada asap meliputi asam asetat, fenol, keton, amina dan benzene. Waktu pengasapan selama 3 minggu menghasilkan kayu yang memiliki nilai ketahanan lebih tinggi dari serangan rayap dan meningkatkan kelas awet kayu.

\section{Pengujian Keawetan terhadap Jamur}

Kayu Medang yang telah diasapkan selanjutnya diuji ketahanannya dari serangan jamur pelapuk kayu Schizophyllum commune Fries. Proses pengujian selama dua belas minggu di dalam wadah uji, dan kondisi kayu setelah pengujian disajikan pada Gambar 2.
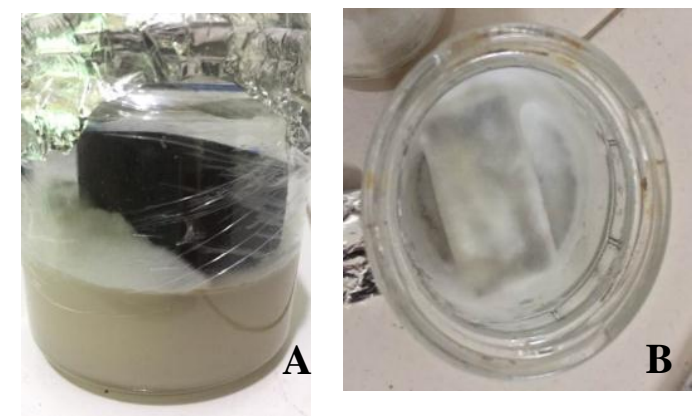

Gambar 2. Pengujian ketahanan kayu Medang (Chinnamomum javanicum) yang diasapkan terhadap jamur pelapuk kayu Schizophyllum commune Fries di dalam wadah uji, A: tampak samping; B: tampak atas

Hasil penelitian menunjukkan kayu Medang yang tidak diasapkan (kontrol) memiliki nilai kehilangan berat kayu yang lebih tinggi daripada kayu Medang yang diasapkan. Nilai rata-rata persentase kehilangan berat kayu Medang yang tidak diasapkan akibat serangan jamur Schizophyllum commune Fries sebesar $6,27 \%$. Nilai rata-rata persentase kehilangan berat kayu Medang yang diasapkan sebesar 2,45\% $3,44 \%$. Semakin lama waktu pengasapan pada kayu Medang menghasilkan nilai ketahanan kayu Medang yang semakin tinggi dari serangan jamur S. commune Fries. Nilai rata-rata persentase kehilangan berat kayu Medang pada kayu yang tidak diasapkan (kontrol) dan kayu Medang yang diasapkan akibat serangan jamur S. commune Fries disajikan pada Gambar 3.

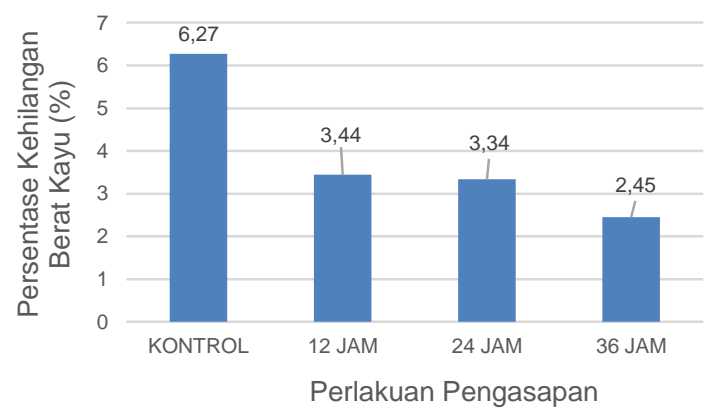

Gambar 3. Nilai rerata persentase kehilangan berat kayu Medang (Chinnamomum javanicum) akibat serangan jamur pelapuk kayu Schizophyllum commune Fries 
Nilai kehilangan berat kayu Medang yang diasapkan akibat serangan jamur pelapuk kayu Schizophyllum commune Fries adalah kurang dari 5\%. Berdasarkan SNI 7207-2014 nilai ketahanan kayu Medang termasuk dalam kelas awet II dengan klasifikasi kelas ketahanan kayu adalah tahan. Hal ini menunjukkan perlakukan pengasapan kayu Medang telah meningkatkan keawetan kayu Medang yang semula kelas III menjadi kelas II.

Sejalan dengan hasil penelitian ini, penelitian Sisilia et al. (2018) menyatakan pengasapan meningkatkan ketahanan kayu Akasia (Acacia mangium) dan Laban (Vitex pubescens) dari serangan jamur Schizophyllum commune Fries. Nilai kehilangan berat kayu Akasia yang diasapkan sebesar 9,55\%, sedangkan kayu Akasia yang tidak diasapkan sebesar $21,68 \%$. Sementara kehilangan berat kayu Laban yang diasapkan sebesar 8,03\% dan pada kayu Laban yang tidak diasapkan sebesar 13,75\%. Peningkatan keawetan kayu Medang yang diasapkan disebabkan sifat anatomis kayu yang mengalami perubahan selama proses pengasapan berlangsung. Hal ini sesuai dengan pernyataan Diba dan Sisillia (2019) bahwa penetrasi asap pada sel kayu menyebabkan perubahan sifat anatomis kayu baik secara radial dan tengensial. Pori-pori kayu mengecil dan menghasilkan peningkatan sifat mekanik kayu yaitu pada kerapatan dan berat jenis kayu. Hal ini menyebabkan hifa jamur sulit untuk mendegradasi dinding sel kayu. Bentuk kerusakan kayu akibat serangan jamur disajikan pada Gambar 4.

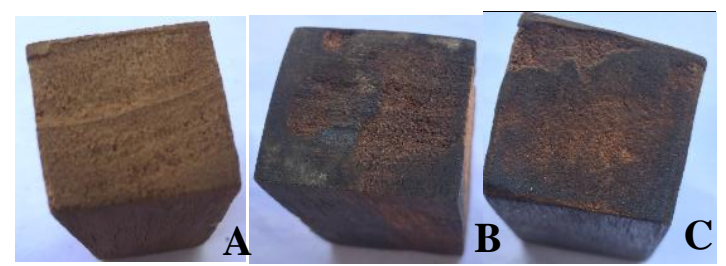

Gambar 4. Kerusakan kayu Medang (Chinnamomum javanicum) yang diasapkan akibat serangan jamur pelapuk kayu Schizophyllum commune Fries, A: pengasapan 12 jam, B: pengasapan 24 jam, $\mathrm{C}$ : pengasapan $36 \mathrm{jam}$
Peningkatan mutu dan keawetan kayu yang banyak dilakukan saat ini adalah penggunaan bahan alam sebagai bahan pengawet kayu serta perlakuan pengasapan (Hadi 2017). Pengujian ketahanan kayu yang diasapkan terhadap jamur masih sedikit dilakukan dibandingkan dengan ketahanan terhadap rayap. Penelitian Hadi (2012) melakukan pengasapan kayu pulai (Alstonia sp.), sugi (Cryptomeria japonica) dan sengon (Falcataria moluccana) selama 2 minggu dan menguji ketahanan kayu dari serangan rayap tanah dan rayap kayu kering. Hasil penelitian menyatakan perlakuan pengasapan meningkatkan keawetan kayu pulai, sugi dan sengon dari serangan rayap tanah Coptotermes curvignathus Holmgren dan Cryptotermes cynocephalus Light.

Pengawetan kayu dengan metode pengasapan dapat meningkatkan keawetan kayu. Penelitian Andika et al. (2019) melakukan pengasapan kayu Bintangur (Chalophyllum sp) dan kayu Medang (Chinnamomum $s p$ ) dengan lama pengasapan 12 jam dan 24 jam. Hasil penelitian menyatakan kayu Bintangur dan Medang memiliki kelas awet II dan tahan terhadap serangan rayap tanah Coptotermes curvignathus Holmgren. Pengasapan kayu mindi (Melia azedarach) and sugi (Cryptomeria japonica) selama 12 jam berhasil meningkatkan ketahanan kayu dari serangan rayap tanah dan rayap kayu kering (Hadi et al., 2010). Selanjutnya pengasapan glulam mangium (Acacia mangium), manii (Maesopsis eminii), dan sengon selama dua minggu ketahanan kayu dari serangam rayap tanah (Hadi et al. 2016).

Penggunaan tempurung kelapa sebagai bahan baku dalam menghasilkan asap memiliki peran dalam meningkatkan keawetan kayu Medang. Menurut Jayanudin dan Suhendi (2012) asap dari tempurung kelapa mengandung senyawa asam asetat, fenol, benzene, keton, ester, methanol dan furankarboksidehide. Senyawa fenol dan asam asetat termasuk senyawa yang memiliki toksisitas terhadap jamur dan rayap. Hal ini sesuai dengan penelitian Oramahi et al. (2018) yang menyatakan senyawa kimia dari berupa asam dan fenol memiliki sifat toksik dan berfungsi sebagai antijamur dan antirayap.

Proses pengasapan yang dilakukan pada suhu $80^{\circ} \mathrm{C}$ membuat air di dalam kayu Medang menguap dan memudahkan penetrasi senyawa 
kimia yang terdapa pada asap untuk masuk ke dalam sel-sel kayu. Ikatan senyawa kimia dari asap dengan kayu terjadi di permukaan kayu dan di bagian dinding sel kayu. Hal ini menyebabkan keawetan kayu meningkat.

Perlakuan pengasapan selama 36 jam menghasilkan nilai kehilangan berat kayu terkecil yaitu 2,45\%. Semakin lama kayu diasapkan semakin banyak senyawa kimia yang terkandung dalam asap menempel pada permukaan kayu dan dibuktikan dengan perbedaan warna yang terjadi setelah sampel kayu diasapkan. Kayu Medang yang diasapkan selama 36 jam memiliki warna coklat kehitaman dan memiliki tingkat toksisitas yang tinggi terhadap jamur. Hasil analisis sidik ragam menunjukkan bahwa pengasapan kayu memiliki pengaruh sangat nyata terhadap kehilangan berat sampel kayu. Lama pengasapan 36 jam menghasilkan kayu Medang dengan warna coklat gelap mengkilap, dan memiliki ketahanan yang tinggi terhadap serangan jamur Schizophyllum commune Fries.

\section{Kesimpulan}

Pengawetan kayu dengan metode pengasapan kayu Medang (Chinnamomum javanicum) berhasil meningkatkan keawetan kayu, yang semula kelas III menjadi kelas II. Perlakuan pengasapan menyebabkan perubahan pada warna kayu karena ikatan senyawa kimia yang terdapat di asap dengan sel-sel kayu. Semakin lama proses pengasapan menghasilkan warna kayu yang semakin gelap dan mengkilap. Pengasapan kayu Medang selama 36 jam menghasilkan nilai kehilangan berat kayu yang paling kecil dan merupakan waktu yang optimal dalam pengawetan kayu Medang untuk meningkatkan ketahanan terhadap serangan jamur Schizophyllum commune Fries. Penelitian dapat dilanjutkan dengan pengujian keawetan kayu Medang terhadap jamur pelapuk kayu skala lapang.

\section{Ucapan terima kasih}

Penulis menyampaikan terima kasih kepada Kementerian Pendidikan dan Kebudayaan yang telah membiayai penelitian dengan skim Penelitian Unggulan Perguruan Tinggi.

\section{Referensi}

Andika R., Diba, F., \& Sisillia, L. (2019). Pengaruh Pengasapan sebagai Pengawet Kayu Bintangur Chalophyllum sp dan kayu Medang Chinnamomum sp Terhadap Serangan Rayap Tanah Coptotermes curvignathus Holmgren. Jurnal Tengkawang 9 (1): 28 - 41 http://dx.doi.org/10.26418/jt.v9i1.33838

Bian Q., May A.A., Kreidenweis S.M., \& Pierce J.R. (2015). Investigation of particle and vapor wall-loss effects on controlled wood-smoke smog-chamber experiment Atmospheric, Chemistry, Physics, Discussion 15:15243-15288 doi:10.5194/acpd-15-15243-2015

Bruns E.A., Krapf M., Orasche J., Huang Y., Zimmermann R., Drinovec L., Mocnik G., I. El-Haddad I., Slowik J.G., Dommen J., Baltensperger U., ... \& Prévôt A.S.H. (2015). Characterization of primary and secondary wood combustion product generated under different burner loads. Atmospheric, Chemistry and Physics 15:2825 - 2841 doi: 10.5194/acp-15-2825-2015

Chhabra, P. S., Canagaratna Ng, N. L., Corrigan M.R., Russell A.L., Worsnop L.M., Flagan D.R., \& Seinfeld, J. H. (2011). Elemental composition and oxidation of chamber organic aerosol. Atmospheric Chemistry and Physics 11: 8827-8845, doi: 10.5194/acp-11-8827- 2011

Crippa, M., DeCarlo, P. F., Slowik, J. G., Mohr, C., Heringa, M. F., Chirico, R., Poulain, L., Freutel, F., Sciare, J., Cozic, J., Di Marco, C. F., Elsasser, M., Nicolas, J. B., Marchand, N., Abidi, E., Wiedensohler, A., Drewnick, F., Schneider, J., Borrmann, S., Nemitz, E., Zimmermann, R., Jaffrezo, J.-L., Prévôt, A. S. H., ... and Baltensperger, U. (2013). Wintertime aerosol chemical composition and source apportionment of the organic fraction in the metropolitan area of Paris, Atmospheric 
Chemistry and Physics 13: 961-981, doi:10.5194/acp-13-961-2013

Diba F and Sisillia L. (2019). The Effect of Traditional Fumigation on Physical, Mechanical and Anatomical Properties of Wooden Handicraft in West Kalimantan. Wood Research Journal, Journal of Indonesian Wood Research Society 10 (2): 39 -47 ISSN 2087-3840 http://ejournalmapeki.org/index.php/wrj /article/view/497/407

Debnath S., Saha A.K., Das P. 2017. Biological Activities of Schizophyllum commune Fr.: A Wild Edible Mushroom of Tripura, North East India. Journal of Mycopathological Research 54 (4): 469475

Fitria, Ermawar R.A., Fatriasari W., Fajriutami T., Yanto D.H.Y., Falah F., \& Euis Hermiati E. (2012). Biopulping of Bamboo Using White-Rot Fungi Schizophyllum commune. Proceding The $2^{\text {nd }}$ International Symposium for Sustainable Humanosphere. Bandung ISSN 2088-9127 hal 8-13

Forlius V.A., Diba F, \& Sisillia L. (2017). Dampak Pengasapan Kayu terhadap Sifat Fisik Kayu Akasia (Acacia mangium Willd) dan Kayu Laban (Vitex pubescens Vahl). Jurnal Hutan Lestari 5 (2): 508 - 513

https://jurnal.untan.ac.id/index.php/jmfk h/article/view/20440/16760

Hadi YS, Massijaya MY, Abdillah IB, Pari G, \& Arsyad WOM. (2020a). Color change and resistance to subterranean termite attack of mangium (Acacia mangium) and sengon (Falcataria moluccana) smoked wood. Journal Korean Wood Science Technology 48(1):1-11 DOI:10.5658/WOOD.2020.48.1.1

Hadi Y.S., Massijaya M.Y., Nandika D., Arsyad W.O.M., Abdillah I.B., Setiono L., \& Amin Y. (2020b). Color change and termite resistance of fast-growing tropical woods treated with kesambi
(Schleichera oleosa) smoke. Jurnal of Wood Science $66 \quad$ (61):1-10 https://doi.org/10.1186/s10086-02001906-y

Hadi, Y. S. (2017). Teknologi Kayu Asap. IPB Press. Bogor

Hadi YS, Nurhayati T, Jasni Yamamoto H, \& Kamiya N. (2010). Smoked wood resistance against termite. Journal Tropical Forest Science 22(2):127-132 https://www.frim.gov.my/v1/JTFSOnlin e/jtfs/v22n2/127-132.pdf

Hadi YS, Nurhayati T, Jasni J, Yamamoto H, \& Kamiya N. (2012). Smoked wood resistance to subterranean and dry wood termites attack. International Biodeterio ration Biodegradation 70:79-81

DOI:10.1016/j.ibiod.2011.06.010

Hadi YS, Efendi M, Massijaya MY, Arinana, \& Pari G. (2016). Subterranean termite resistance of smoked glued laminated lumber made from fast growing tree species from Indonesia. Wood Fiber Sci 48(3):211-21

https://wfs.swst.org/index.php/wfs/articl e/view/2284/2309

Husbands A. and Cranford S. (2019). A Material Perspective of Wood, Smoke, and BBQ. Matter 1: 1092-1095. Elsevier corporation. https://doi.org/10.1016/j.matt.2019.10.01 $\underline{4}$

Iramayana, Taskirawati I., \& Arif A. (2019). Keragaman Jamur pada Log dan Kayu Gergajian Nyatoh (Palaquium sp). Jurnal Perennial, 15 (1) :8-15 ISSN: 1412-7784

https://journal.unhas.ac.id/index.php/per ennial/article/view/6729/pdf

Istikowati WT, Sutiya B, Sunardi, Ishiguri G, \& Yokota S. (2019). Karakteristik Anatomi Kayu Terap, Medang dan Balik Angin dari Hutan Sekunder di Kalimantan Selatan Indonesia. Jurnal Hutan Tropis 7(2): 172-180 
http://eprints.ulm.ac.id/8944/1/Jurnal_H utan_Tropis_Volume_7_No_2.pdf

Istikowati WT, Aiso H, Sunardi, Sutiya B, Ishiguri $\mathrm{F}$, Ohshima $\mathrm{J}$, lizuka $\mathrm{K}$, \& Yokota S. (2016). Wood, Chemical, and Pulp Properties of Woods from LessUtilized Fast-Growing Tree Species Found in Naturally Regenerated Secondary Forest in South Kalimantan, Indonesia, Journal of Wood Chemistry and Technology, 00:1-9

DOI: 10.1080/02773813.2015.1124121

Istikowati, W.T.; Ishiguri, F.; Aiso, H.; Hidayati, F.; Tanabe, J.; lizuka, K.; Sutiya, B.; Wahyudi, I.; \& Yokota, S. (2014). Physical and mechanical properties of woods from three native fast-growing species in a secondary forest in South Kalimantan, Indonesia. Forest Product Journal 64(1/2): 48-54

https://doi.org/10.13073/FPJ-D-13-00069

Ishiguri $\mathrm{F}$, Masubuchi N, Yokota S, \& Yoshizawa N. (2005). Changes in the physical and chemical properties of six Japanese softwoods caused by lengthy smoke-heating treatment. Journal Wood Science 51:161-166 https://doi.org/10.1007/s10086-004-0620$\underline{8}$

Jasni (2016). Keawetan Alami 57 Jenis Kayu Indonesia dengan Pengujian di Bawah Naungan. Jurnal Penelitian Hasil Hutan. 34(3): 179-186 http://doi.org/10.20886/jphh.2016.34.3. 179-188

Jayanudin \& Suhendi, E. (2012). Identifikasi Komponen Kimia Asap Cair Tempurung Kelapa dari Wilayah Anyer Banten. Jurnal Agroekotek 4 (1): 39 - 46

https://jurnal.untirta.ac.id/index.php/jav/a $\underline{\text { rticle/view/619 }}$

Juanita, Oramahi H.A., \& Diba F. (2020). Potensi Asap Cair dari Kayu Bintangur sebagai Biopestisida Pengendali Jamur Schizophyllum commune. Bioma: Jurnal Biologi dan Pembelajaran Biologi 5
(1):22-32 p-ISSN 2527-7111; e-ISSN 2528-1615

DOI : 10.32528/bioma.v5i1.3684

Mariana E, Ariyanti, \& Erniwati (2013). Uji

Retensi dan Efektivitas Tanaman Kumis

Kucing (Orthosiphon aristatus) terhadap

Serangan Rayap Tanah (Coptotermes

Sp) pada Kayu Durian (Durio zibethinus). Jurnal Warta Rimba 1(1): $35-40$

http://jurnal.untad.ac.id/jurnal/index.php /WartaRimba/article/view/1943

Mulia S, Murningsih, Jumari, \& Alhamd L. (2017). Keanekaragaman Jenis Anggota Lauraceae dan Pemanfaatannya di Cagar Alam Dungus Iwul Kabupaten Bogor Jawa Barat. Jurnal Biologi 6(1): 1-10 https://ejournal3.undip.ac.id/index.php/b iologi/article/view/19517

Oramahi HA, Yoshimura T, Diba F, Setyawati D, \& Nurhaida (2018). Antifungal and antitermitic activities of wood vinegar from oil palm trunk. Journal Wood Science 64:311-317

https://doi.org/10.1007/s10086-018$\underline{1703-2}$

Palm LMN, Deric C, Philip OY, Winston JQ, Mordecai AG, and Albert D. (2011). Characterization of polycyclic aromatic hydrocarbons (PAHs) present in smoked fish from Ghana. Advanced Journal of Food Science and Technology 3(5):332338

https://studylib.net/doc/13311432/advan ce-journal-of-food-science-andtechnology-5-3---332-338

Penus, Diba, F. \& Sisillia, L. (2016). Pengaruh Lama Pengasapan Terhadap Sifat Fisik dan Mekanik Kayu Laban Vitex pubescens Vahl dan Akasia Acacia mangium Wild. Jurnal Hutan Lestari 5 (3) : $732-740$

http://dx.doi.org/10.26418/jhl.v5i3.2153 $\underline{6}$

Royani D.S., Marasabessy I., Santoso J., \& Nurimala M. (2015). Rekayasa Alat Pengasapan Ikan Tipe Kabinet (Model 
Oven). Jurnal Aplikasi Teknologi Pangan 4 (2):74-78

http://www.jatp.ift.or.id/index.php/jatp/ article/view/130/95

Sisillia L, Diba, F. VA Andri, \& CG Piana (2018). Peningkatan mutu kayu dan kualitas kayu konstruksi dengan teknik peng asapan: kajian sifat kimia kayu dan keawetan terhadap jamur Schizophyllum commune Fries. Journal of Lignocellu lose Technology 2 (1), 38-43

https://docplayer.net/196199230-

Journal-of-lignocellulose-

technology.html

Standar Nasional Indonesia [SNI] Nomor 7207(2014). Uji Ketahanan Kayu dan Produk Kayu Terhadap Organisme Perusak Kayu. Jakarta: Badan Standarisasi Nasional Indonesia

Susan D. \& Retnowati A. (2017). Catatan Beberapa Jamur Makro dari Pulau Enggano: Diversitas dan Potensinya. Berita Biologi Jurnal Ilmu-Ilmu Hayati 16 (3): 243-256

https://e-journal.biologi.lipi.go.id/ index.php/berita_biologi/article/view/29 39/2900 